\title{
Medicine, Science and the Law http://msl.sagepub.com/
}

\section{Age at death estimation from bone histology in Malaysian males \\ Faridah Mohd Nor, Robert F Pastor and Holger Schutkowski \\ Med Sci Law published online 4 November 2013 \\ DOI: $10.1177 / 0025802413506573$}

The online version of this article can be found at:

http://msl.sagepub.com/content/early/2013/10/31/0025802413506573

\section{Published by: \\ (S)SAGE \\ http://www.sagepublications.com}

On behalf of:

British Academy of Forensic Sciences

Additional services and information for Medicine, Science and the Law can be found at:

Email Alerts: http://msl.sagepub.com/cgi/alerts

Subscriptions: http://msl.sagepub.com/subscriptions

Reprints: http://www.sagepub.com/journalsReprints.nav

Permissions: http://www.sagepub.com/journalsPermissions.nav

>> OnlineFirst Version of Record - Nov 4, 2013

What is This? 


\section{Age at death estimation from bone histology in Malaysian males}

Medicine, Science and the Law $0(0) \mathrm{I}-6$

(C) The Author(s) 2013 Reprints and permissions: sagepub.co.uk/journalsPermissions.nav DOI: $10.1177 / 00258024 \mid 3506573$ msl.sagepub.com

\author{
Faridah Mohd Nor', Robert F Pastor ${ }^{2}$ and Holger Schutkowski ${ }^{3}$
}

\begin{abstract}
Estimation of age from microscopic examination of human bone utilizes bone remodeling. This allows regression equation to be determined in a specific population based on the variation in osteon turnover in different population. The aim of this study was to provide age estimation for Malaysian males. Ground undecalcified cross sections were prepared from long limb bones of 50 deceased males aged between 21 and 78 years. Ten microstructural parameters were measured and subjected to multivariate regression analysis. Results showed that osteon count had the highest correlation with age $(R=0.43)$, and age was estimated to be within 10.94 years of the true value in $98 \%$ of males. Cross-validation of the equation on 50 individuals showed close correspondence of true ages with estimated ages. Further studies are needed to validate and expand these results.
\end{abstract}

\title{
Keywords
}

age, bone, forensic, Haversian canal, histomorphometry, human, osteon

\section{Introduction}

Morphologic skeletal features are used widely to perform age at death estimation in human remains, particularly useful for people aged less than 50 years, ${ }^{1}$ while a histological approach has been advocated as the method of choice for age estimation mainly, for people aged over 50 years. $^{2}$ Bone structure changes with age by turnover, remodeling and modeling, and growth, which alters the morphology and histology of the bone throughout an individual's life. ${ }^{3}$ Age is an important factor, in which there is an increase in bone porosity with increasing age as remodeling results in increased bone resorption and less bone formation. ${ }^{3}$

Combined approaches by using both gross and micro-morphological parameters have been used to offer better results, ${ }^{4,5}$ including cortical thickness (CT) and histologic parameters. Kerley's method, ${ }^{6}$ which requires a complete bone cross section, is widely cited as the most accurate of all histologic methods. Kerley ${ }^{6}$ utilized various histologic parameters such as secondary osteons, osteon fragments, non-Haversian canals, and percentage of lamellar bone in specific regions on cross sections from femorae, tibiae, and fibulae.

There is a distinct variation in the remodeling pattern in various parts of the bone. Patterns of microstructural parameters differ in different cross sections of the same bone and in different locations of one cross section. ${ }^{7}$ Any one part of the bone may not be representative of the entire cross section of the bone. Hence, the measurements from the entire cross section will be the best method to use. ${ }^{7}$ The mid-diaphyseal part of a long bone was used to determine age in many studies, ${ }^{1,8}$ as this part of the bone tends to be more robust and last through exposure to weathering changes and predator or scavenger damage., ${ }^{9,10}$ Cortical bones of fibula, humerus, and ulna were used to estimate age in the population. ${ }^{1}$ The anterior midshaft of femur was also widely used to study age prediction histologically. ${ }^{11,12}$

Various factors such as genetic, biomechanic, and environmental factors are known to have a major contribution to the morphology and microstructure of bone in the population. ${ }^{13}$ The type of physical activity and metabolic and biochemical needs of the body in response to bone formation could lead to a distinctive bone microstructure and bone mass. ${ }^{14}$ Individuals have been under-aged by 29.2 years due to poor nutrition resulting in significant retardation of osteonal growth in ribs. ${ }^{15,16}$ Other related factors such as life history, ${ }^{17}$ disease,${ }^{18}$ physical activity,${ }^{17}$ diet and length of daylight, ${ }^{19,20}$ and nutritional stress ${ }^{21}$ have

\footnotetext{
Department of Pathology, Universiti Kebangsaan Malaysia Medical Centre (UKMMC), Malaysia

${ }^{2}$ Department of Anthropology, University of Oregon, USA

${ }^{3}$ School of Applied Sciences, University of Bournemouth, UK

\section{Corresponding author:}

Faridah Mohd Nor, Department of Pathology, Universiti Kebangsaan Malaysia Medical Centre Forensic Unit, UKMMC, Jalan Yaacob Latif, Bandar Tun Razak, Kuala Lumpur 56000, Malaysia.

Email: mnfaridah@gmail.com
} 
some influence in determining the rate of skeletal ageing in an individual, which finally lead to variability in bone remodeling. ${ }^{22}$

Applications of histological age estimation have been based largely on Western populations, and therefore continued to be used as a reference for age estimation of other populations. ${ }^{19,23-25}$ However, individual human skeletons have been shown to demonstrate age-related changes and progresses at different rates leading to differences in bone microstructure ${ }^{19,26,20}$ and bone mass. ${ }^{27}$ Hence, the method used widely for Europeans and Africans is not readily applicable to populations of other ancestry due to under- or over-ageing, as reported in other case studies. ${ }^{19,28}$ It is therefore important to develop population-specific equation for age estimation to account for the varying rates of remodeling in different populations. ${ }^{2}$ The aim of this study, therefore, is to provide regression equations for investigating correlations between variation in microstructural parameters and age at death in Malaysian males.

\section{Methods}

The study materials comprised specimens from 50 males, aged 21-78 years (mean 41.68, standard deviation (SD) 11.85) collected from the mortuaries of Forensic unit, Hospital Universiti Kebangsaan Malaysia and Hospital Kuala Lumpur. The procedure for legal handling of human bones is stated in the Criminal Procedure Code, Section 331 (part 2) of the Malaysian Law, which stated that the postmortem examination of the human body may be extended to dissection, and analysis of any portion of the body may be retained for further investigation and research purposes. $^{29}$

Samples were taken from humerii, ulnae, radii, femorae, fibulae, and tibiae, and only specimens confirmed to be free from any pathology following gross and microscopic examination were used. While other studies relied exclusively on histologic variables, this study included the morphologic variables such as CT and medullary cavity diameter (MCD), which were measured on the bone by using digital calipers. CT and MCD were determined to the nearest $0.01 \mathrm{~mm}$ after the bone marrow was removed.

A complete circumferential mid-diaphyseal $2 \times 2 \mathrm{~cm}$ fragment was removed in a plane that was transverse to the longitudinal axis of the long bone. Bone fragments were defatted with diethyl ether in soxhlet and embedded in Buehler Epothin ${ }^{\mathrm{TM}}$ epoxy resin mixture using the manufacturer's specifications. Thin sections of $30 \mu \mathrm{m}$ were produced with a sawmicrotome (Leica SP 1600), finished with a grinder/ polisher (Phoenix Beta Buehler) and mounted with a cover slip on a microscopic slide using Histomount.

Microscopic analysis was performed under transmitted light at $100 \times$ magnification with an Olympus BX 51 microscope. Measurements were made on four

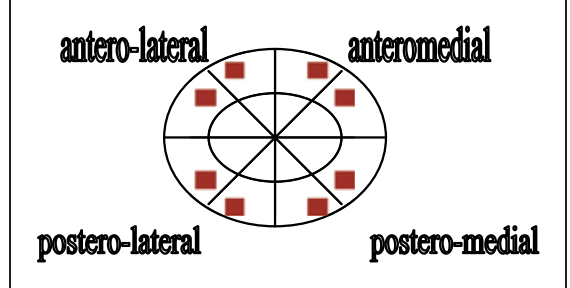

Figure I. Bone thin cross-section: Eight fields for histological measurements. Note that histological measurements were made on eight fields: two areas of anteromedial, anterolateral, posteromedial, and posterolateral.

subperiosteal fields: anteromedial, anterolateral, posteromedial, and posterolateral quadrants, thus avoiding the linea aspera. Each field was subdivided into two subfields (Figure 1) separated by the width of one square grid measuring $10 \times 10 \mu \mathrm{m}\left(100 \mu \mathrm{m}^{2}\right)$, which was calibrated by an objective micrometer (AX0001, Olympus). Histologic parameters, namely osteon count (OC), osteon diameter (OD), Haversian canal diameter (HCD), osteon area (OA), Haversian canal area (HCA), osteon perimeter (OP), Haversian canal perimeter (HCP), and Haversian lamellae count (HLC) were measured using a commercially available image analysis program (SIS Soft Imaging System 3.2 Software Package). The morphologic and histologic variables are collectively known as microstructural parameters.

Measurements of osteons followed the criteria as described in Wachter et al. ${ }^{30}$ with some modifications. Measurement of osteons, Haversian canals, and lamellae was made on intact osteons and canals. OC comprised the aggregate number of osteons and osteon fragments. In previous criteria, osteons and osteon fragments were counted separately. Osteons were counted as such that half or more than half of its Haversian canal was present in the visual field, and osteon fragments at the periphery of the field were also included, even if it was only partly within the field.

The complete slides of 10 individuals were tested for interobserver analysis with respect to osteon counting. Three independent observers, namely a forensic pathologist with a few years experience in bone histology, an experienced forensic anthropologist, and a forensic archaeologist were involved in the observational analysis. The osteon counting was done without any knowledge of the sample's age, origin, or type of bone for blinding purposes. The analysis was repeated after one-week interval.

\section{Statistical analysis}

Correlations between microstructural parameters and age were tested by Pearson's ( $\mathrm{R}$ ) correlation, and age regression equations were established using multivariate regression analysis in SPSS version 15.0. ${ }^{31}$ All 10 parameters were subjected to stepwise multivariate regression analysis with age as dependent parameter 
so that only equation with the lowest standard error of estimates (SEE) was chosen. Cross-validation of the equation by independent sample $t$-test was performed on 50 deceased persons to determine the applicability of the method. The difference in osteon counting in each observer was tested by using paired $t$-test, and the difference in osteon counting among all observers was tested by using one-way analysis of variance (ANOVA).

\section{Results and discussion}

Assessment of osteon counting showed reasonable agreement by all observers. By using paired $t$-test, osteon counting in two different days showed a significant difference in one observer $(P<0.01)$ but were generally agreeable in two observers (Tables 1 and 2). Assessment in osteon counting showed no significant difference between all observers by using the ANOVA test (Table 3).

The osteon parameters, OD, OC, OA, and OP showed significant correlation with age $(P<0.01)$ (Table 4) with $\mathrm{OD}(\mathrm{R}=-0.44)$ scoring highest, followed by $\mathrm{OC}(\mathrm{R}=0.40)$, area $(\mathrm{R}=-0.35)$, and perimeter $(\mathrm{R}=-0.35)$ in descending order. This meant

Table I. Descriptive statistics of OC I and OC 2 for all observers.

\begin{tabular}{|c|c|c|c|c|}
\hline \multicolumn{2}{|c|}{ Observer $1 / 2 / 3$} & \multirow{2}{*}{$\frac{\text { Mean }}{23.5}$} & \multirow{2}{*}{$\frac{N}{10}$} & \multirow{2}{*}{$\frac{S D}{9.44}$} \\
\hline I. Pair I & $\mathrm{OCI}$ & & & \\
\hline & $\mathrm{OC2}$ & 21.4 & 10 & 6.5 \\
\hline \multirow[t]{2}{*}{ 2. Pair 2} & $\mathrm{OCI}$ & 21.8 & 10 & 10.46 \\
\hline & $\mathrm{OC2}$ & 15.9 & 10 & 7.84 \\
\hline \multirow[t]{2}{*}{ 3. Pair 3} & $\mathrm{OCI}$ & 17 & 10 & 10.46 \\
\hline & OC2 & 17 & 10 & 7.53 \\
\hline
\end{tabular}

A slight difference in osteon counting in two different days in all observers is noted.

SD: standard deviation; OC: osteon count.
Table 2. Paired sample t-test between the observers in osteon counting.

\begin{tabular}{llll}
\hline & $t$ & df & Sig. (two-tailed) \\
\hline Pair I OCI-OC2 & 1.13 & 9 & 0.28 \\
Pair 2 OCI-OC2 & 3.20 & 9 & $0.01^{\mathrm{a}}$ \\
Pair 3 OCI-OC2 & 0 & 9 & 1.00 \\
\hline
\end{tabular}

${ }^{\text {a }}$ Correlation is significant at the 0.01 level (two-tailed). OC: osteon count.

Table 3. One-way analysis of variance (ANOVA) of the mean $O C$ between the three observers.

\begin{tabular}{lrll}
\hline & df & F & Sig. \\
\hline Between groups & 2 & 1.09 & 0.35 \\
Within groups & 27 & & \\
Total & 29 & & \\
\hline
\end{tabular}

Table 4. Correlation analysis for the relation between age and microstructural parameters.

\begin{tabular}{llll}
\hline Parameter & Pearson correlation, R & Sig (two-tailed) & $\mathrm{N}$ \\
\hline OC & 0.40 & $0.0 \mathrm{I}^{\mathrm{a}}$ & 50 \\
HCD & 0.02 & 0.84 & 50 \\
HCA & 0.09 & 0.50 & 50 \\
HCP & 0.02 & 0.88 & 50 \\
HLC & 0.03 & 0.82 & 50 \\
CT & 0.04 & 0.77 & 50 \\
MCD & -0.06 & 0.63 & 50 \\
OD & -0.44 & $0.01^{\mathrm{a}}$ & 50 \\
OA & -0.35 & $0.01^{\mathrm{a}}$ & 50 \\
OP & -0.35 & $0.01^{\mathrm{a}}$ & 50 \\
\hline
\end{tabular}

${ }^{a}$ Correlation is significant at the 0.01 level (two-tailed).

OC: osteon count; HCD: Haversian canal diameter; HCA: Haversian canal area; HCP: Haversian canal perimeter; HLC: Haversian lamellae count; CT: cortical thickness; MCD: medullary cavity diameter; OD: osteon diameter; OA: osteon area; OP: osteon perimeter.

Table 5. Age estimating equation derived from stepwise regression analysis.

\begin{tabular}{|c|c|c|c|c|c|}
\hline No & Equations & $\begin{array}{l}\text { Correlation } \\
\text { coefficient }\end{array}$ & $\begin{array}{l}\text { Multiple } \\
\mathrm{R}^{2}\end{array}$ & SEE & Sig. \\
\hline I & $\begin{array}{l}Y=93.48+0.36 \mathrm{OC}-1.63 \mathrm{HCD}+0.22 \mathrm{HCA}+0.09 \mathrm{HCP}-0.13 \mathrm{HLC}-0.5 \mathrm{ICT} \\
-1.08 \mathrm{MCD}-0.47 \mathrm{OD}-0.15 \mathrm{OA}+0.17 \mathrm{OP}\end{array}$ & 0.64 & 0.42 & 10.12 & $0.01^{\mathrm{a}}$ \\
\hline 2 & $\begin{array}{l}Y=92.57+0.30 \mathrm{O}-1.59 \mathrm{HCD}+0.22 \mathrm{HCA}+0.08 \mathrm{HCP}-0.48 \mathrm{CT}-1.05 \mathrm{MCD} \\
-0.46 \mathrm{OD}-0.14 \mathrm{OA}+0.17 \mathrm{OP}\end{array}$ & 0.64 & 0.41 & 9.99 & $0.01^{\mathrm{a}}$ \\
\hline 3 & $\mathrm{Y}=86.44+0.36 \mathrm{OC}-0.55 \mathrm{HCD}+0.22 \mathrm{HCA}+0.07 \mathrm{HCP}-0.03 \mathrm{MCD}$ & 0.64 & 0.41 & 9.88 & $0.01^{\mathrm{a}}$ \\
\hline 4 & $\begin{array}{l}Y=82.48+0.290 \mathrm{C}-1.40 \mathrm{HCD}+0.23 \mathrm{HCA}-1.1 \mathrm{IMCD}-0.42 \mathrm{OD} \\
-0.18 \mathrm{OA}+0.190 \mathrm{P}\end{array}$ & 0.64 & 0.41 & 9.78 & $0.01^{\mathrm{a}}$ \\
\hline 5 & $Y=94.98-1.65 \mathrm{HCD}+0.26 \mathrm{HCA}-1.23 \mathrm{MCD}-0.48 \mathrm{OD}-0.200 \mathrm{~A}+0.22 \mathrm{OP}$ & 0.64 & 0.40 & 9.72 & $0.01^{\mathrm{a}}$ \\
\hline 6 & $Y=157.46-1.42 \mathrm{HCD}+0.22 \mathrm{HCA}-1.35 \mathrm{MCD}-0.54 \mathrm{OD}+0.04 \mathrm{OP}$ & 0.62 & 0.39 & 9.72 & $0.01^{\mathrm{a}}$ \\
\hline 7 & $Y=156.57-1.47 \mathrm{HCD}+0.23 \mathrm{HCA}-1.30 \mathrm{MCD}-0.36 \mathrm{OD}$ & 0.61 & 0.38 & 9.71 & $0.01^{\mathrm{a}}$ \\
\hline
\end{tabular}

${ }^{a}$ Correlation is significant at the 0.01 level (two-tailed).

OC: osteon count; HCD: Haversian canal diameter; HCA: Haversian canal area; HCP: Haversian canal perimeter; HLC: Haversian lamellae count; CT: cortical thickness; MCD: medullary cavity diameter; OD: osteon diameter; OA: osteon area; OP: osteon perimeter; SEE: standard error of estimate. 
that overall osteon size decreased with age $(P<0.05) .^{32}$ In contrast, Haversian canal parameters, namely HCA, HCD, and HCP showed positive correlations with age, which suggested that Haversian canal size increased with age indicating higher prevalence of young osteons, as they usually have larger Haversian canals. $^{33}$

Stepwise multivariate regression analysis resulted in several age regression equations with SEE between

Table 6. Coefficients derived from regression analysis.

\begin{tabular}{llrll}
\hline & & \multicolumn{2}{l}{ Unstandardized coefficients } & \\
\cline { 2 - 4 } \multicolumn{2}{l}{ Model } & B & Standard error & Sig. \\
\hline 7 & (Constant) & 156.571 & 26.278 & 0.000 \\
& HCD & -1.477 & 0.646 & 0.027 \\
& HCA & 0.230 & 0.074 & 0.003 \\
MCD & -1.309 & 0.596 & 0.033 \\
OD & -0.369 & 0.080 & 0.000 \\
\hline
\end{tabular}

Dependent variable: age.

HCD: Haversian canal diameter; HCA: Haversian canal area; MCD: medullary cavity diameter; OD: osteon diameter.
10.12 and 9.71 years. The equation with the smallest SEE (1) is based on four parameters: HCD, HCA, $\mathrm{MCD}$, and $\mathrm{OD}(\mathrm{SEE}=9.71 ; P<0.01)$ (Tables 5 and 6):

$$
\begin{aligned}
\mathrm{Y}= & 156.57-1.47(\mathrm{HCD})+0.23(\mathrm{HCA}) \\
& -1.30(\mathrm{MCD})-0.36(\mathrm{OD})
\end{aligned}
$$

It is pertinent to mention that this equation is applicable to all long limb bones, whether it is from upper or lower limb.

It reflects the observation that the HCA is increasing with age. In contrast, Haversian canal decreases with age for which no reason could be offered at this stage but may be attributed to insufficient sample. OD gets smaller due to shrinking of the overall size of an adult Haversian system as bone matures. It also reflects that MCD decreases with age. Crossvalidation of the equation on 50 individuals of this study showed close approximation of ages between true ages and estimated ages (Table 7), and there was no significant difference between the two ages $(P<0.97)$ (Table 8). The mean of true age for all

\begin{tabular}{|c|c|c|c|c|c|c|c|}
\hline No. & $\begin{array}{l}\text { Known age } \\
\text { (years) }\end{array}$ & $\begin{array}{l}\text { Estimated age } \\
\text { (years) }\end{array}$ & $\begin{array}{l}\text { Difference } \\
\text { (years) }\end{array}$ & No. & $\begin{array}{l}\text { Known age } \\
\text { (years) }\end{array}$ & $\begin{array}{l}\text { Estimated age } \\
\text { (years) }\end{array}$ & $\begin{array}{l}\text { Difference } \\
\text { (years) }\end{array}$ \\
\hline I & 38 & 39.85 & -1.85 & 26 & 22 & 44.04 & -22.04 \\
\hline 2 & 37 & 45.52 & -8.52 & 27 & 40 & 45.37 & -5.37 \\
\hline 3 & 41 & 39.17 & 1.83 & 28 & 63 & 45.44 & 17.56 \\
\hline 4 & 28 & 32.67 & -4.67 & 29 & 47 & 38.08 & 8.92 \\
\hline 5 & 39 & 38.64 & 0.36 & 30 & 67 & 50.75 & 16.25 \\
\hline 6 & 78 & 53.40 & 24.60 & 31 & 52 & 47.67 & 4.33 \\
\hline 7 & 46 & 38.85 & 7.15 & 32 & 50 & 46.19 & 3.81 \\
\hline 8 & 37 & 41.47 & -4.47 & 33 & 64 & 59.63 & 4.37 \\
\hline 9 & 56 & 44.33 & 11.67 & 34 & 49 & 35.23 & 13.77 \\
\hline 10 & 52 & 49.29 & 2.71 & 35 & 29 & 40.17 & -11.17 \\
\hline II & 42 & 42.33 & -0.33 & 36 & 27 & 39.91 & $-|2.9|$ \\
\hline 12 & 39 & 32.43 & 6.57 & 37 & 40 & 29.77 & 10.23 \\
\hline 13 & 39 & 43.83 & -4.83 & 38 & 53 & 41.73 & 11.27 \\
\hline 14 & 52 & 52.83 & -0.83 & 39 & 33 & 35.39 & -2.39 \\
\hline 15 & 21 & 40.47 & -19.47 & 40 & 32 & 30.07 & 1.93 \\
\hline 16 & 42 & 41.14 & 0.86 & 41 & 34 & 42.33 & -8.33 \\
\hline 17 & 52 & 49.97 & 2.03 & 42 & 38 & 45.52 & -7.52 \\
\hline 18 & 33 & 29.87 & 3.13 & 43 & 25 & 31.84 & -6.84 \\
\hline 19 & 38 & 46.29 & -8.29 & 44 & 53 & 54.10 & -1.10 \\
\hline 20 & 50 & 43.26 & 6.74 & 45 & 31 & 31.17 & -0.17 \\
\hline 21 & 32 & 46.25 & -14.25 & 46 & 33 & 37.65 & -4.65 \\
\hline 22 & 47 & 41.37 & 5.63 & 47 & 32 & 39.47 & -7.47 \\
\hline 23 & 35 & 32.50 & 2.50 & 48 & 37 & 50.53 & -13.53 \\
\hline 24 & 48 & 47.90 & 0.10 & 49 & 45 & 35.58 & 9.42 \\
\hline 25 & 26 & 23.97 & 2.03 & 50 & 40 & 46.29 & -6.29 \\
\hline
\end{tabular}

Table 7. Comparisons of known age and estimated age for all males. 
Table 8. Paired sample t-test for known age and estimated age.

\begin{tabular}{|c|c|c|c|c|c|c|c|c|}
\hline & & Mean & $N$ & $S D$ & SEM & $\mathrm{t}$ & $d f$ & $\begin{array}{l}\text { Sig. } \\
\text { (two-tailed) }\end{array}$ \\
\hline \multirow[t]{2}{*}{ Pair I } & Age & 41.6800 & 50 & 11.85187 & $1.676 \mid \mathrm{I}$ & .038 & 49 & .970 \\
\hline & Agel & 41.6304 & 50 & 7.33467 & 1.03728 & & & \\
\hline
\end{tabular}

Age: known age; Agel: estimated age; SD: standard deviation.

Table 9. Age regression equation by Yoshino et al., ${ }^{\prime}$ Kerley, ${ }^{6}$ Ericksen, ${ }^{8}$ Thompson, ${ }^{17}$ Nor et al., ${ }^{34}$ Singh and Gunberg, ${ }^{35}$ Stout, ${ }^{36}$ and this study.

\begin{tabular}{|c|c|c|c|c|c|}
\hline & Regression equation & $\mathrm{R}$ & $\mathrm{R}^{2}$ & SEE & Sig. \\
\hline Kerley $^{6}$ & $57.811-1.728($ non-Haversian $)+0.013(\text { non-Haversian })^{2}$ & 0.815 & - & 13.85 & - \\
\hline Singh and Gunberg ${ }^{35}$ & $89.01-0.62(H C D)$ & $0.937^{\mathrm{a}}$ & - & 3.82 & 0.05 \\
\hline Thompson ${ }^{17}$ & $\begin{array}{l}28.978+128.557(\mathrm{HLC} \text { and HCA })-1.79 \mathrm{CT}-7.543(\mathrm{OP} / \mathrm{OC}) \\
-7.633(\text { Total OP })+2.688(\mathrm{OC})\end{array}$ & 0.862 & - & 7.06 & - \\
\hline Ericksen ${ }^{8}$ & $\begin{array}{l}92.42+1.070 \mathrm{C}+2.5 \text { (type II osteon })+0.25(\text { fragment })+0.3 \\
\text { (resorption spaces }-1.52(\text { primary canal })-0.57 \text { (mean percent } \\
\text { unremodeled bone) }-0.6 \mathrm{I} \text { (mean percent osteonal bone }) \\
-0.35 \text { (mean percent fragmental bone) }\end{array}$ & 0.67 & - & 10.08 & - \\
\hline Stout & $-12.239+2.873$ (Total osteon count) & 0.682 & - & - & - \\
\hline This study & $156.57-1.47(\mathrm{HCD})+0.23(\mathrm{HCA})-\mathrm{I} .30(\mathrm{MCD})-0.36(\mathrm{OD})$ & $0.6 \mathrm{I}^{\mathrm{b}}$ & 0.38 & 9.71 & 0.01 \\
\hline Yoshino et al.' & $5.72+2.89(\mathrm{OC})$ & $0.58^{\mathrm{b}}$ & - & 9.28 & 0.01 \\
\hline Nor et al. ${ }^{34}$ & $5.484+1.19(\mathrm{OC})-0282(\mathrm{OD})+0.706(\mathrm{HCD})$ & $0.58^{\mathrm{b}}$ & 0.346 & 12.62 & 0.01 \\
\hline
\end{tabular}

${ }^{\mathrm{a} P}<0.05$

${ }^{\mathrm{b}} \mathrm{P}<0.01$

OC: osteon count; HCD: Haversian canal diameter; HCA: Haversian canal area; HLC: Haversian lamellae count; CT: cortical thickness; MCD: medullary cavity diameter; OD: osteon diameter; OP: osteon perimeter; SEE: standard error of estimate.

cases was 41.68 years, and the mean of estimated age was 41.63 years.

Yoshino et al. ${ }^{1}$ and this study showed that Japanese and Malaysians have shown approximation in SEE values, i.e., $\mathrm{SEE}=9.28$ and $\mathrm{SEE}=9.71$, respectively (Table 9) as they were both Asians. The correlations for regressions were comparable for Yoshino et al. ${ }^{1}(\mathrm{R}=0.58)$, Nor et al. $^{34}(\mathrm{R}=0.58)$, and this study $(\mathrm{R}=0.61)$ (Table 9$)$. Other studies produced regressions with SEE ranging from 9 to 13 years as in Kerley, ${ }^{6}$ Ericksen, ${ }^{8}$ Thompson, ${ }^{17}$ Nor et al., ${ }^{34}$ Singh and Gunberg, ${ }^{35}$ and this study (Table 9). According to the literature, the age gap in years may vary between 9 and 13 years by using histomorphometric method. Further reduction of SEE would need refinement of the measured parameters. In conclusion, the equation in this study may be used to perform age estimation in the Malaysian males. Further research would be important for further validation and expansion of sample population.

\section{Conclusion}

For the Malaysian male population, a quantitative histological method of age estimation was analyzed by collecting the specimens and analyzing 10 microstructural parameters in the mid-diaphyseal cortex of upper and lower long limb bones. In microscopic transverse sections, quantitative assessments were taken on four subperiosteal locations, namely anteromedial, anterolateral, posteromedial, and posterolateral on the bone thin section. Interobserver analysis showed reasonable agreement between experienced and inexperienced examiners in the assessment of osteon counting. Despite the generally encouraging outcome, it is recommended that this study be used as a preliminary step to a more extensive research in future, which would include confounding factors, namely different types of bones, ancestry affiliation, dietary intake, disease, and environment in the estimation of age.

\section{Declaration of conflicting interests}

The authors declare that there is no conflict of interest.

\section{Funding}

The authors thank the Malaysian Government for funding the research project.

\section{Contributorship}

Faridah Mohd Nor - planned the study, compiled the data, and wrote the paper. Robert F Pastor and Holger Schutkowski - supervised the work and edited the paper. 


\section{Acknowledgements}

The authors thank the Universiti Kebangsaan Malaysia Medical Centre and Hospital Kuala Lumpur for having allowed access to the human bone samples.

\section{References}

1. Yoshino M, Imaizumi K, Miyasaki S, et al. Histological estimation of age at death using microradiographs of humeral compact bone. Forensic Sci Int 1994; 64: 191-198.

2. Thompson DD. Microscopic determination of age at death in an autopsy series. J Forensic Sci 1981; 26: 470-475.

3. Crowder CM and Stout SD. Bone histology: an anthropological perspective. USA: Taylor and Francis, 2012, p.230.

4. Baccino E, Ubelaker DH, Hayek LAC, et al. Evaluation of seven methods of estimating age at death from mature human skeletal remains. $J$ Forensic Sci 1999; 44: 931-936.

5. Narasaki S. Estimation of age at death by femoral osteon remodeling: application of Thompson's core technique to modern Japanese. $J$ Anthropol Soc Nippon 1990; 98: 29-38.

6. Kerley ER. The microscopic determination of age in human bone. Am J Phys Anthropol 1965; 23: 149-164.

7. Drusini AG. Notes and comments: sampling location in cortical bone histology. Am J Phys Anthropol 1996; 100: 609-610.

8. Ericksen MF. Histologic estimation of age at death using the anterior cortex of the femur. Am $J$ Phys Anthropol 1991; 84: 171-179.

9. Navani S, Shah J and Levy P. Determination of sex by costal cartilage calcification. Am J Roentgenol Radium Ther Nucl Med 1970; 108: 771-774.

10. Murad TA and Boddy MA. A case with bear facts. J Forensic Sci 1987; 32: 1819-1826.

11. Maat GJR, Maes A, Aarents MJ, et al. Histological age prediction from the femur in a contemporary Dutch sample. The decrease of nonremodeled bone in the anterior cortex. J Forensic Sci 2006; 51: 230-237.

12. Dirkmaat D. A companion to forensic anthropology. UK: Wiley-Blackwell, 2012.

13. Frost HM. Bone remodeling and its relationship to metabolic bone diseases. vol. III, Springfield: Charles C. Thomas, 1973, pp.67-70.

14. Diana MG and Dunnell RC. Identification of fragmentary bone from the Pacific. J Archaeol Sci 2010; 37: 957-970.

15. DiGangi EA and Moore MK. Research methods in human skeletal biology. Oxford: Elsevier Inc, 2013, p.371.

16. Paine RR and Brenton BP. Dietary health does affect histological age assessment: an evaluation of the Stout and Paine (1992) age estimation equation using secondary osteons from the rib. J Forensic Sci 2006; 51: 489-492.

17. Thompson DD. The core technique in the determination of age at death in skeletons. J Forensic Sci 1979; 24: 902-915.
18. Kelin M and Frost HM. The numbers of bone resorption and formation foci in rib. Henry Ford Hosp Med Bull 1964; 12: 527-536.

19. Thompson DD and Gunness-Hey M. Bone mineralosteon analysis of Yupik-Inupiaq skeletons. $A m J$ Phys Anthropol 1981; 55: 1-7.

20. Richman EA, Ortner DJ and Schulter-Ellis FP. Differences in intra-cortical bone remodeling in three aboriginal American populations: possible dietary factors. Calcif Tissue Int 1979; 28: 209-214.

21. Garn SM. The earlier gain and later loss of cortical bone in nutritional perspective. Springfield: Charles C. Thomas, 1970.

22. Stout SD. Methods of determining of age at death using bone microstructure. In: Saunders SR and Katzenberg MA (eds) Skeletal biology of past peoples: research methods. New York: Wiley Liss, 1992, pp.21-35.

23. Cho H, Stout SD, Madsen RW, et al. Population-specific histological age estimating method: a model for known African-American and European-American skeletal remains. J Forensic Sci 2002; 47: 12-18.

24. Aeillo LC and Molleson T. Are microscopic ageing techniques more accurate than macroscopic ageing techniques? J Archaeol Sci 1993; 20: 689-704.

25. Walker RA. An assessment of histological age determination techniques (abstract). Am J Phys Anthropol 1990; 81: 313.

26. Pratte DG and Pfeiffer S. Histological age estimation of a cadaveral sample of diverse origins. Can Soc Forensic Sci J 1999; 32: 155-167.

27. Ericksen MF. Aging changes in the medullary cavity of the proximal femur in Americans Blacks and Whites. Am J Phys Anthropol 1979; 51: 563-570.

28. Ubelaker DH. Estimation of age at death from histology of human bone. In: Zimmerman MR and Angel JL (eds) Dating and age determination of biological materials. London: Croom Helm, 1986, pp.240-247.

29. Laws of Malaysia. Criminal procedure code (FMS Cap 6). Kuala Lumpur: ILBS, 1995, p.113.

30. Wachter NJ, Krischak GD, Mentzel $M$, et al. Correlation of bone mineral density with strength and microstructural parameters of cortical bone in vitro. Bone 2002; 31: 90-95.

31. SPSS Science for Windows (Inc. 2005, Version 13.0), Chicago: SPSS.

32. Burr DB, Ruff $\mathrm{CB}$ and Thompson DD. Patterns of skeletal histologic change through time: a comparison of an archaic Native American population with modern populations. Anat Rec 1990; 226: 307-313.

33. Junqueira LC and Carneiro J. Basic histology: text and atlas. New York: McGraw-Hill, 2005, pp.134-148.

34. Nor FM, Pastor RF and Schutkowski H. Population specific equation for estimation of age: a model for known Malaysian population. Malays $J$ Forensic Pathol Sci 2006; 1: 15-28.

35. Singh IJ and Gunberg DL. Estimation of age at death in human males from quantitative histology of bone fragments. Am J Phys Anthropol 1970; 33: 373-382.

36. Stout SD. The use of bone histomorphometry in skeletal identification: the case of Francisco Pizarro. J Forensic Sci 1986; 31: 296-300. 